\title{
Application Of The Self-Directed Learning (SDL) Learning Model In EnVironmental Engineering Courses For Students Of The Building Engineering Education Study Program, University Of Palangka Raya, Academic Year 2020/2021
}

\section{Penerapan Model Pembelajaran Self-Directed Learning (SDl) Pada Mata Kuliah Teknik Lingkungan Mahasiswa Prodi Pendidikan Teknik Bangunan Universitas Palangka Raya Tahun Akademik 2020/2021}

\author{
Tarita Aprilani Sitinjak ${ }^{1}$, Lola Cassiophea ${ }^{2}$, Ni Putu Diah Agustin Permanasuri ${ }^{3}$, Artike Telambanua ${ }^{4}$, Alen Setiawan $^{5}$ \\ 1)2)3) Jurusan Teknologi dan Kejuruan Prodi Pendidikan Teknik Bangunan, FKIP, \\ 4)5) Mahasiswa Prodi Pendidikan Teknik Bangunan, FKIP, \\ Universitas Palangkaraya, Jl. H.Timang Tunjung Nyaho Palangkaraya Kode Pos 73112
}

Email: taritasitinjak@yahoo.co.id

\begin{abstract}
Teachers have to work the learning assignments from home (continuously and as a controlled routine) constantly and have the potential to be unproductive to work in a completely new circumtance and without the supervision of a leader (intense). However, there are a number of ways to deal with this problem, especially preventing teachers from being confused in applying appropriate and effective learning models, as well as continuous professional development. They definitely want to be productive in using their time during the Covid 19 pandemic. Time management has to be carried out and controlled properly to improve quality. Teacher professionalism is as a professional educator. The solution for teachers is required to be able to design learning media as an innovation by utilizing online media (online). This research is motivated by the learning outcomes of Building Engineering Education students who program Environmental Engineering Courses that are still relatively low just under 60 (Cscore). Self-Directed Learning (SDL) is learning in which using the conceptualization, design, implementation and evaluation of learning projects and these are directly revealed by students. The key point is whether students choose to concentrate on learning. This type of research is classroom action research which is carried out online, this is due to the covid-19 pandemic. Quantitative data in the form of numbers or scores obtained from student learning outcomes tests. The instrument used in this research is the final test of student learning outcomes. Then the parameters in this study use the learning outcomes and independence of Building Engineering Education students in the Environmental Engineering course. The output of this research will be published in the Balanga Journal.
\end{abstract}

Key words: Learning Model, Self-Direct Learning, Environmental Engineering

\section{ABSTRAK}

Guru harus mengerjakan tugas pembelajaran dari rumah (secara kontinyu dan sebagai rutinitas terkendali) secara berkelanjutan dan berpeluang tidak produktif bekerja di lingkungan yang sama sekali baru dan tanpa pengawasan pimpinan (secara inten). Namun ada sejumlah cara menyiasati persoalan itu, terutama mencegah para guru kebingungan dalam menerapkan model pembelajaran yang tepat dan efektif, serta pengembangan profesi berkelanjutan, pasti ingin produktif dalam memanfaatkan waktu di masa pandemic Covid 19. Manajemen waktu harus dilakukan dan dikendalikan secara baik untuk meningkatkan kualitas profesionalitas guru sebagai pendidik professional. Solusinya, tenaga pengajar dituntut dapat mendesain media pembelajaran sebagai inovasi dengan memanfaatkan media daring (online). Penelitian ini dilatar belakangi oleh hasil belajar mahasiswa Pendidikan Teknik Bangunan yang memprogramkan Mata Kuliah Teknik Lingkungan masih relatif rendah di bawah skor 60 (nilai C). SelfDirected Learning (SDL) adalah pembelajaran di mana konseptualisasi, desain, pelaksanaan dan evaluasi proyek pembelajaran diarahkan oleh mahasiswa. Poin kuncinya adalah apakah mahasiswa memilih berkonsentrasi pada pembelajaran. Jenis penelitian ini adalah penelitian tindakan kelas yang dalam pelaksanaannya dilakukan secara daring (online), hal ini disebabkan oleh pandemic covid-19 yang belum berakhir. Data kuantitatif berupa angka atau skor yang diperoleh dari tes hasil belajar mahasiswa. Instrumen yang digunakan dalam penelitian ini yaitu tes akhir hasil belajar mahasiswa. Parameter dalam penelitian ini adalah hasil belajar dan kemandirian mahasiswa Pendidikan Teknik Bangunan pada mata kuliah Teknik Lingkungan. Rencana atau target akan dipublikasikan kedalam Jurnal Balanga.

Kata Kunci : Model Pembelajaran, Self-Direct Learning, Teknik Lingkungan 


\section{PENDAHULUAN}

Dalam proses pembelajaran mata kuliah IImu Lingkungan di Program Studi Pendidikan Teknik Bangunan Universitas Palangka Raya, pada masa pandemic covid 19 pembelajaran dilakukan secara daring dan ditemukan beberapa permasalahan diantaranya peserta didik mengatakan bahwa matakuliah IImu Lingkungan sulit dipahami terutama konsep dasarnya.

Peserta didik cenderung hanya menguasai contoh soal yang diberikan, apabila diberikan sedikit variasi pada soal, peserta didik tidak dapat mengerjakannya, karena kemampuan mereka sebatas kemampuan menghafal, sedangkan kemampuan untuk menguasai konsep dasar Teknik Lingkungan masih sangat rendah.

Berdasarkan kenyataan tersebut, maka perlu dilakukan perbaikan dalam kegiatan pembelajaran dalam rangka meningkatkan kemampuan peserta didik untuk menganalisis dan mengerjakan soal yang bervariasi dari contoh yang diberikan pendidik untuk mencapai hasil belajar di atas skor lulus 60 (nilai C). Salah satu cara yang dapat digunakan adalah dengan penggunaan model pembelajaran yang lebih mengutamakan keaktifan peserta didik dan member kesempatan mahasiswa untuk mengembangkan potensinya secara maksimal, dan model yang dimaksud yaitu model pembelajaran self-directed learning. Selfdirected learning merupakan kemandirian belajar adalah suatu metode pembelajaran yang dilakukan seseorang untuk meningkatkan pengetahuan, keahlian, dan prestasi melalui inisiatif sendiri dalam perencanaan, pelaksanaan, dan evaluasi bergantung pada kemampuan individu dalam mengelola pembelajaran sesuai dengan otonomi yang dimiliki, meskipun nantinya membutuhkan bantuan atau nasihat dari orang lain. Self-directed learning menurut Mariam (2004) merupakan kondisi pembelajaran mahasiswa membuat inisiatif sendiri dalam perencanaan, pelaksanaan, dan evaluasi dari pengalaman belajar yang diambil dari berbagai sumber atau literatur.

\section{METODE PENELITIAN}

Metode yang digunakan dalam penelitian ini adalah metode penelitian tindakan kelas yang dengan sengaja dilakukan untuk merencanakan, melaksa- nakan kemudian mengamati dampak dari pelak- sanaan tindakan tersebut pada subjek penelitian.

Tabel 1. Teknik Pengumpulan Data dan InstrumenPenelitian

\begin{tabular}{|c|c|c|c|c|}
\hline No & Jenis Data & $\begin{array}{c}\text { Teknik } \\
\text { Pengumpulan Data }\end{array}$ & Instrumen Penelitian & Waktu \\
\hline 1. & $\begin{array}{c}\text { Kemandirian } \\
\text { belajar }\end{array}$ & Angket & Angket kemandirian belajar & di awal siklus I dan di akhir siklus I dan II \\
\hline & Hasil belajar & Tes & Tes akhir siklus & di akhir siklus I dan siklus II \\
\cline { 3 - 5 } & & Kontrak belajar & Kontrak belajar & setiap pertemuan \\
\hline
\end{tabular}

\section{Langkah Penelitian \\ Tahap Persiapan}

Pada tahap ini dilakukan hal-hal yaitu membuat instrument penelitian, menganalisi uji coba instrument Tahap Pelaksanan Penelitian

Pada tahap ini dilakukan hal-hal sebagai berikut:

a) Dosen membagi menjadi 2 kelompok. Kelompok pertama adalah mahasiswa yang menggunakan model pembelajaran Self-directed Learning sementara kelompok ke-2 adalah kelompok mahasiswa yang menggunakan model konvensional

b) Dosen mengadakan pre-test pada kedua kelompok untuk mengetahui pemahaman awal mahasiswa tentang materi Teknik Lingkungan.

c) Mahasiswa diberikan perlakuan berupa pembelajaran daring materi Limit dengan menerapkan model Self-directed learning untuk kelompok 1 dan model konvensional untuk kelompok ke-2

d) Melakukan post-test pada kedua kelompok yang bertujuan untuk mengetahui seberapa besar perbedaan pemahaman pembelajaran serta hasil belajar siswa dengan diberikannya model selfdirected learning dan metode konvensional

Instrumen penelitian adalah alat atau fasilitas yang digunakan peneliti untuk mengumpulkan data agar dalam pekerjaan lebih mudah dan dapat hasil yang akurat dan lebih baik, lengkap dan sistematis sehingga mudah untuk diolah (Arikunto, 2002:134).

Instrumen penelitian yang dipergunakan dalam peneliti ini adalah berupa:

a. Pre test atau test tertulis kepada mahasiswa dengan bentuk essay yang disusun sesuai dengan materi yang diajarkan. Instrumen ini digunakan untuk mengetahui kemampuan awal siswa dalam ketercapaian proses pembelajaran sebelum dan setelah menggunakan model pembelajaran self directed learning.

b. Post test yang bertujuan untuk mengetahui apakah semua materi yang sudah diajarkan dapat dikuasai sebaik-baikya oleh mahasiswa. Materi test yang akan diberikan pada saat post test sama dengan pre test awal. 
Validitas dilakukan untuk mengetahui ketepatan dan kelayakan instrument sebagai alat ukur terhadap konsep atau variabel yang akan diukur, sehingga apa yang seharusnya diukur benar-benar dapat terukur.

\begin{tabular}{|c|c|c|}
\hline \multicolumn{3}{|c|}{ Tabel 2. Data DistribusiFrekuensi Pre-test (Test Awal) } \\
\hline Nomor Subjek & Nilai Pretest & Kelompok \\
\hline 1. & 65 & 1 \\
\hline 2. & 60 & 1 \\
\hline 3. & 66 & 1 \\
\hline 4. & 70 & 1 \\
\hline 5. & 62 & 1 \\
\hline 6. & 76 & 1 \\
\hline 7. & 75 & 1 \\
\hline 8. & 68 & 1 \\
\hline 9. & 70 & 1 \\
\hline 10. & 82 & 2 \\
\hline 11. & 92 & 2 \\
\hline 12. & 85 & 2 \\
\hline 13. & 87 & 2 \\
\hline 14. & 91 & 2 \\
\hline 15. & 93 & 2 \\
\hline 16. & 88 & 2 \\
\hline 17. & 95 & 2 \\
\hline 18 & 94 & 2 \\
\hline
\end{tabular}

\section{HASIL DAN PEMBAHASAN} Hasil Pre-Test (Tesawal)

Hasil yang diperoleh dari soal dalam bentuk essay sebanyak 3 butir, soal dengan tingkat pengerjaan mudah, sedang dan sukar diberikan kepada 18 mahasiswa Prodi Pendidikan Teknik Bangunan Universitas Palangka Raya, dalam pre-test ini diberikan untuk langkah awal yang dilakukan peneliti untuk Mengukur kemampuan mahasiswa sebelum mengikuti matakuliah Teknik Lingkungan.
Contoh perhitungan untuk awal Bulan Januari Perhitungan ETo dengan metode Penman adalah sebagai berikut.

Dari Tabel 3 didapat bahwa semua nilai hasil tes masih di bawah rata-rata, nilai kurang dari 60 yang berarti mahasiswa dinyatakan tidak lulus. Kondisi ini masih belum diberikan perlakuan Self-Directed Learning dengan Google classroom maupun zoom meeting

\begin{tabular}{|c|c|c|}
\hline \multicolumn{3}{|c|}{ Tabel 3 Data hasil Post Test (Tes Akhir) } \\
\hline $\begin{array}{c}\text { Nomor } \\
\text { Subjek }\end{array}$ & Nilai Pretest & Kelompok \\
\hline 1. & 31 & 1 \\
\hline 2. & 27 & 1 \\
\hline 3. & 50 & 1 \\
\hline 4. & 38 & 1 \\
\hline 5. & 40 & 1 \\
\hline 6. & 45 & 1 \\
\hline 7. & 56 & 1 \\
\hline 8. & 33 & 1 \\
\hline 9. & 34 & 1 \\
\hline 10. & 36 & 2 \\
\hline 11. & 53 & 2 \\
\hline 12. & 57 & 2 \\
\hline 13. & 55 & 2 \\
\hline 14. & 54 & 2 \\
\hline 15. & 48 & 2 \\
\hline
\end{tabular}




\section{Hasil Post-test (Test Akhir)}

\begin{tabular}{|l|l|l|}
\hline 16. & 57 & 2 \\
\hline 17. & 42 & 2 \\
\hline 18 & 43 & 2 \\
\hline
\end{tabular}

Post-test yang diberikan merupakan hasil dari kemampuan peserta didik setelah dilakukanya perlakuan dengan menggunakan model pembelajaran Self-directed Learning. Post-test diberikan untuk melihat pengaruh sesudah menggunakan model pembelajaran hybrid learning yang dilihat dengan berdasarkan pre-test yang sebelumnya dilakukan. Selain itu juga post-test merupakan evaluasi untuk melihat ketercapain hasil belajar setelah dilakukan kegiatan pembelajaran

Tabel 2. Menunjukkan bahwa terjadi peningkatan nilai yang cukup signifikan baik untuk kelompok I (metode konvensional) maupun untuk kelompok 2 (metode SelfDirected Learning). Semua mahasiswa mendapatkan nilai diatas 60 yang berarti semua mahasiswa dinyatakan lulus.

\section{Uji Validitas}

Uji validitas butir soal dilakukan menggunakan analisa Produk Momen dengan bantuan software SPSS 15, diperoleh hasil yang ditunjukkan oleh Tabel 5. Dari Tabel 5 diperoleh bahwa baik untuk soal 1 maupun soal 2 diperoleh bahwa nilai sig. (2-tailed) < 0,05 dan memiliki nilai Pearson Correlation positif sehingga dapat disimpulkan bahwa item soal instrumen adalah valid.

\section{Uji Reliability}

Pengujian reliabilitas dilakukan dengan menggunakan koefisien Alpha Cronbach. Instrumen dapat dikatakan andal/reliabel bila memiliki koefisien Alpha Cronbach lebih dari 0,6. Uji reliabilitas dengan menggunakan software SPPS 15, diperoleh hasil sebagai berikut:

Tabel 4. Hasil Uji Reliabilitas

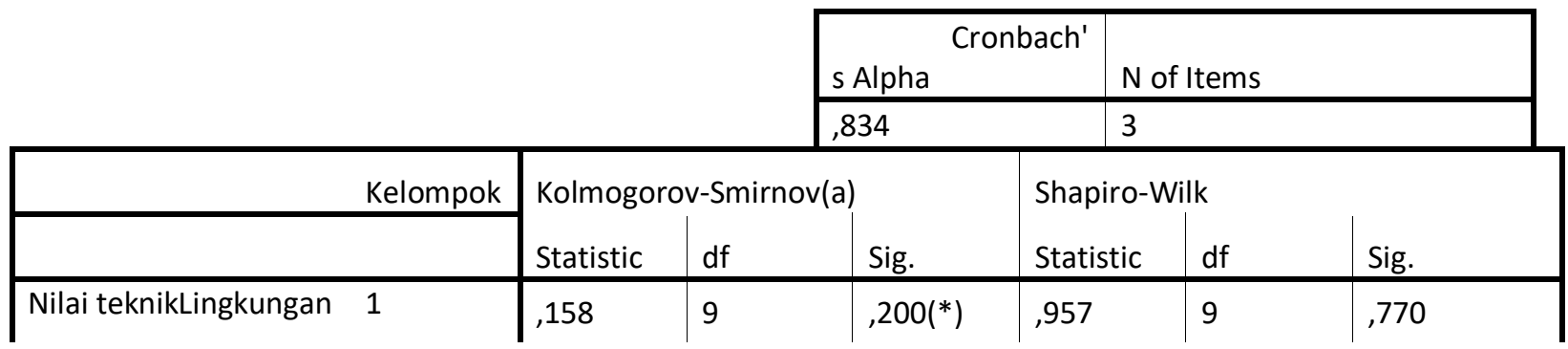




\begin{tabular}{l|l|l|l}
2 &, 236 & 9 &, 158
\end{tabular}

Dari Tabel 4 diperoleh nilai Cronbach's Alpha adalah 0,834 , hal ini menunjukkan bahwa $r 11 \geq 0,70$ (reliabel). Jadi dapat disimpulkan bahwa item soal adalah reliabel.

\section{Pengujian Hipotesis}

Analisis data penelitian, data statistik dilakukan dengan bantuan software SPSS 15, jenis-jenis dari uji penelitian adalah uji normalitas, uji homogenitas dan uji independent sample $T$ test. Berikut akan dijelaskan secara lebih detail hasil dari ketiga uji tersebut.

\section{Uji Normalitas}

Dengan menggunakanbantuan software SPSS 15.00 dapat diketahui apakah data bersifat normal atau tidak, dikarenakan penelitian ini memiliki sampel yang kurang dari lima puluh data maka hasil uji normalitas yang digunakan adalah

\begin{tabular}{l|l|l}
, 888 & 9 &, 191
\end{tabular}

menggunakan nilai signifikan dari Shapiro-Wilk. Dengan persyaratan sebagai berikut:

Nilai signifikan> 0,05 maka data berdistribusi normal

Nilai signifikan< 0,05 maka data tidak berdistribusi normal

Tabel 5. Hasil Uji Validitas

* Correlation is significant at the 0.05 level (2-tailed).

**Correlation is significant at the 0.01 level (2-tailed).

Tabel 6 Hasil Uji Normalitas Untuk Pra-Test

* This is a lower bound of the true significance.

\section{a. Test normalitas soal pra-test}

\begin{tabular}{|c|c|c|c|c|c|}
\hline & & Soal 1 & Soal 2 & Soal 3 & Total \\
\hline \multirow[t]{3}{*}{ Soal 1} & Pearson Correlation & 1 & ,447 &, $500(*)$ &, $706(* *)$ \\
\hline & Sig. (2-tailed) & & ,063 & ,035 & ,001 \\
\hline & $\mathrm{N}$ & 18 & 18 & 18 & 18 \\
\hline \multirow[t]{3}{*}{ Soal 2} & Pearson Correlation & ,447 & 1 &, $894(* *)$ &, $928(* *)$ \\
\hline & Sig. (2-tailed) & ,063 & & ,000 & ,000 \\
\hline & $\mathrm{N}$ & 18 & 18 & 18 & 18 \\
\hline \multirow[t]{3}{*}{ Soal 3} & Pearson Correlation &, $500(*)$ &, $894(* *)$ & 1 &, $945(* *)$ \\
\hline & Sig. (2-tailed) & ,035 & ,000 & & ,000 \\
\hline & $\mathrm{N}$ & 18 & 18 & 18 & 18 \\
\hline \multirow[t]{3}{*}{ Total } & Pearson Correlation &, $706(* *)$ &, $928(* *)$ &, $945(* *)$ & 1 \\
\hline & Sig. (2-tailed) & ,001 & ,000 & ,000 & \\
\hline & $\mathrm{N}$ & 18 & 18 & 18 & 18 \\
\hline
\end{tabular}

Dari hasil normalitas tes u untuk pra-test, diperoleh bahwa nilai signifikansi Shapiro-Wilk adalah 0,770 untuk kelompok 1 (menggunakan metode konvensional) dan 0,191 untuk kelompok 2 (menggunakan metode Self-Directed Learning/SDL). Kedua nilai ini lebih besar dari 0,05, dapat disimpulkan bahwa data untuk nilai post-test adalah berdistribusi normal.

\section{b. Test normalitas soal post-test}

Dari hasil normalitas tes u untuk pra-test, diperoleh bahwa nilai signifikansi Shapiro-Wilk adalah 0,822 untuk kelompok 1 (menggunakan metode konvensional) dan 0,634 untuk kelompok 2 (menggunakan metode Self-Directed Learning/SDL). 
Kedua nilai ini lebih besar dari 0,05, dapat disimpulkan bahwa data untuk nilai post-test adalah berdistribusi normal.

Tabel 7 Hasil Uji NormalitasUntukPra-Test

\begin{tabular}{|ll|l|l|l|l|l|l|}
\hline & Kelompok & \multicolumn{2}{|l|}{ Kolmogorov-Smirnov(a) } & \multicolumn{3}{l|}{ Shapiro-Wilk } \\
\hline & & Statistic & df & Sig. & Statistic & df & Sig. \\
\hline Nilai teknikLingkungan & 1 &, 134 & 9 &, $200\left(^{*}\right)$ &, 962 & 9 &, 822 \\
& 2 &, 174 & 9 &, $200\left(^{*}\right)$ &, 945 & 9 &, 634 \\
\hline
\end{tabular}

* This is a lower bound of the true significance.

Tabel 8 Hasil Independent Sample Test

Independent Samples Test

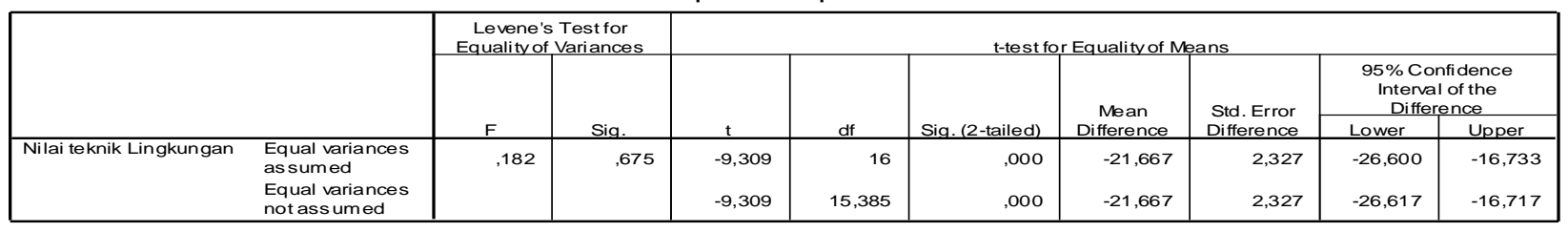

Tabel 9 Luaran yang dicapai

\begin{tabular}{|c|c|c|c|}
\hline No & \multicolumn{2}{|l|}{ Jenis Luaran } & Indikator Capaian \\
\hline 1 & \multicolumn{2}{|l|}{ Publikasi ilmiah di jurnal nasional (ber ISSN) ${ }^{11}$} & published \\
\hline \multirow{2}{*}{2} & \multirow{2}{*}{ Pemakalah dalam temu ilmiah²) } & Nasional & - \\
\hline & & Lokal & terdaftar \\
\hline 3 & \multicolumn{2}{|l|}{ Bahan ajar ${ }^{3)}$} & tidak ada \\
\hline 4 & \multicolumn{2}{|l|}{$\begin{array}{l}\text { Luaran lainnya jika ada (Teknologi Tepat Guna, } \\
\text { Model/Purwarupa/Desain/Karya Seni/Rekayasa Sosial) }{ }^{4)}\end{array}$} & tidak ada \\
\hline 5 & \multicolumn{2}{|l|}{ Tingkat Kesiapan Teknologi (TKT) } & tidak ada \\
\hline
\end{tabular}

\section{Uji Homogenitas}

Dengan bantuan SPSS 15, diperoleh apakah data bersifat homogeny atau tidak. Dasar pengambilan keputusan adalahs ebagaiberikut :

Jika nilai signifikansi> 0,05 maka distribusi data adalah homogen

Jika nilai signifikansi $<0,05$ maka distribusi data adalah tidak homogen.

Untuk hasil dari perhitungan menggunakan software SPSS 15, yang dapat dilihat pada tabel independent sample test diperoleh bahwa nilai signifikansi dari Levene's test for equality of variances adalah 0,675. Nilai ini, 0,675 >0,05 yang menunjukkan bahwa data berdistribusi homogen.

\section{Pengujian Hipotesis}

Untuk pengujian hipotesis dilakukan dengan uji independent sample $T$ test. Uji independent sample $\mathrm{T}$ test, analisisnya dibantu dengan menggunakan software SPSS 15, dengan dasar pengambilan keputusan sebagai berikut:

Jika nilai Sig. (2-tailed) < 0,05 maka terdapat perbedaan yang signifikan antara hasil belajar dengan metode konvensional dan metode SelfDirected Learning (SDL) akan tetapi jika nilai Sig. (2-tailed) > 0,05 maka tidak ada perbedaan yang signifikan antara hasil

Belajar dengan metode konvensional dan metode Self-Directed Learning (SDL). Dari Tabel 7 independent sample test diperoleh bahwa nilai sig (2-tailed) untuk equal variances assumed adalah 0,000 . Nilai $0,000<0,05$ ini menunjukkan bahwa maka ada perbedaan yang signifikan antara hasil belajar dengan metode konvensional dan metode Self-Directed Learning (SDL). Hasil analisa baik baik dilihat secara langsung dari hasil ujian ataupun dianalisa dengan uji $\mathrm{T}$ test diperoleh bahwa dengan diterapkan metode Self-Directed Learning nilai pada mata kuliah Teknik Lingkungan 
meningkat secara signifikan. Hal ini menunjukkan dengan menerapkan metode pembelajaran yang tepat, memberi peluang kepada mahasiswa untuk lebih aktif dalam kegiatan pembelajaran makasiswa semakin dapat lebih mengembangkan kapasitasnya, lebih kreatif sehingga dapat meningkatkan hasil belaja rmereka.

\section{Luaran Yang Dicapai}

Luaran penelitian ini ditunjukkan pada Tabel 9.

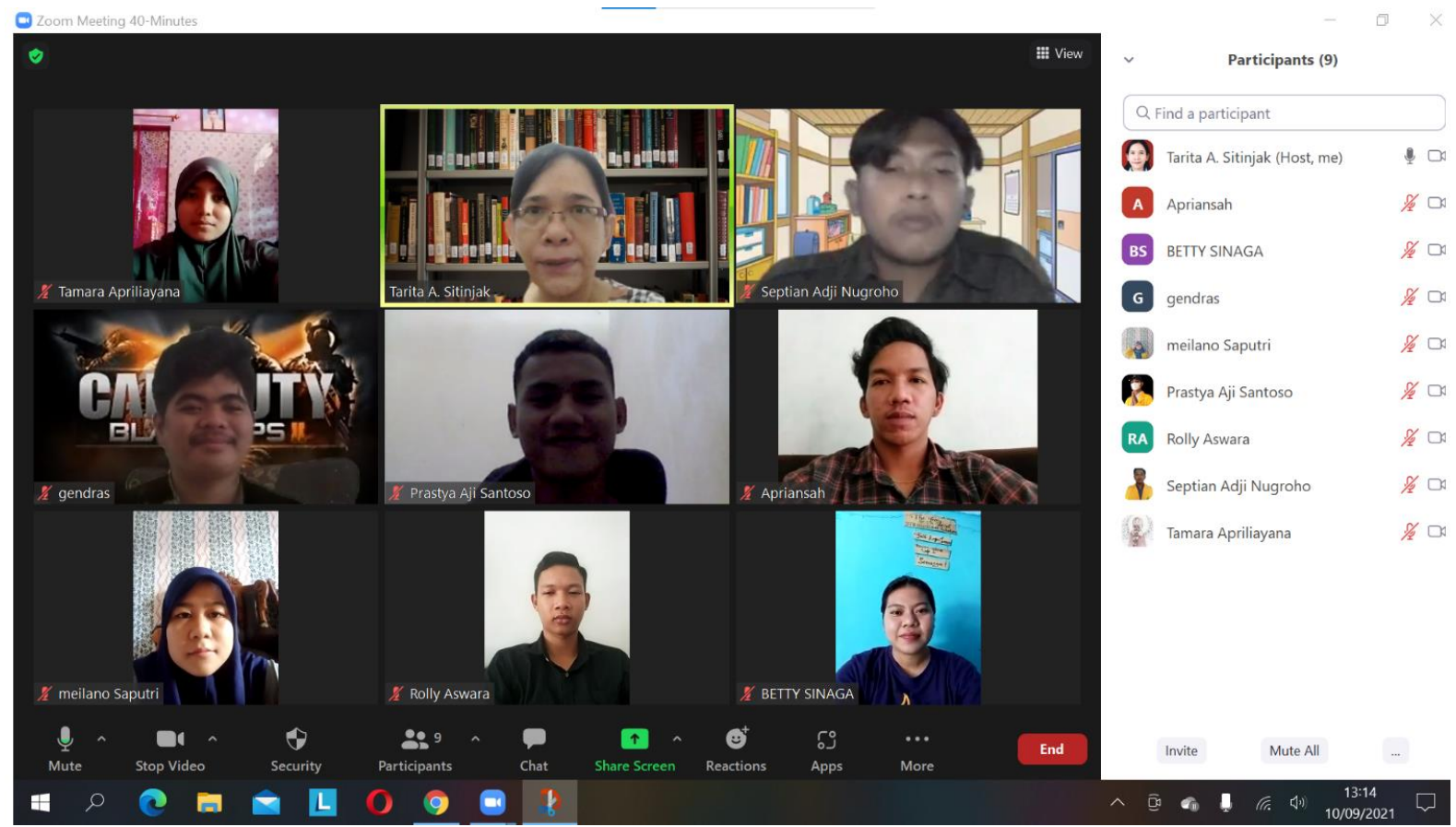

Gambar 1. Pertemuan Awal Dengan Zoom Meeting (Pre-test)

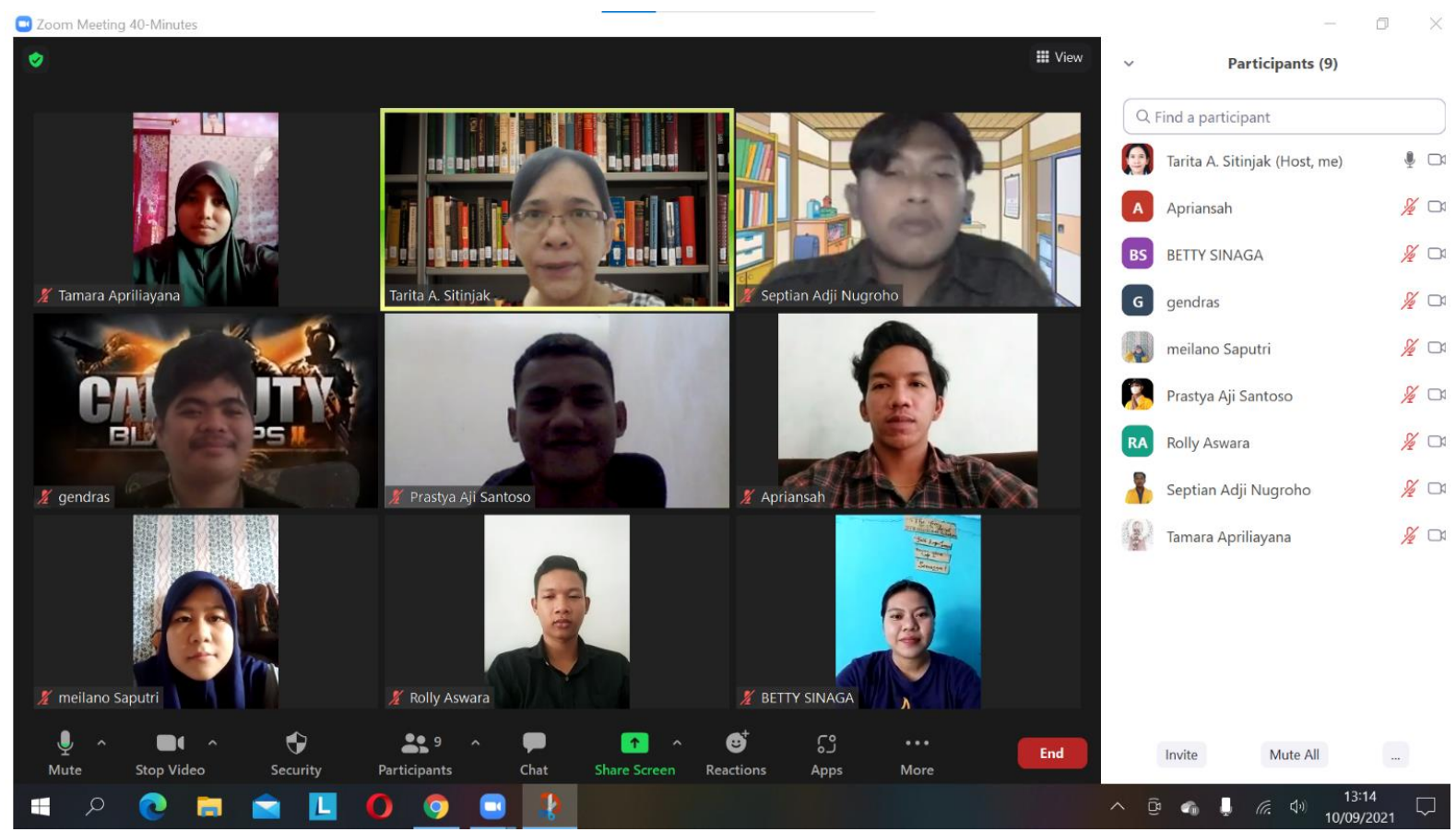

Gambar 2. Pertemuan Dengan Zoom Meeting (Kelompok 1 Dengan Metode Pembelajaran Konvensional) 


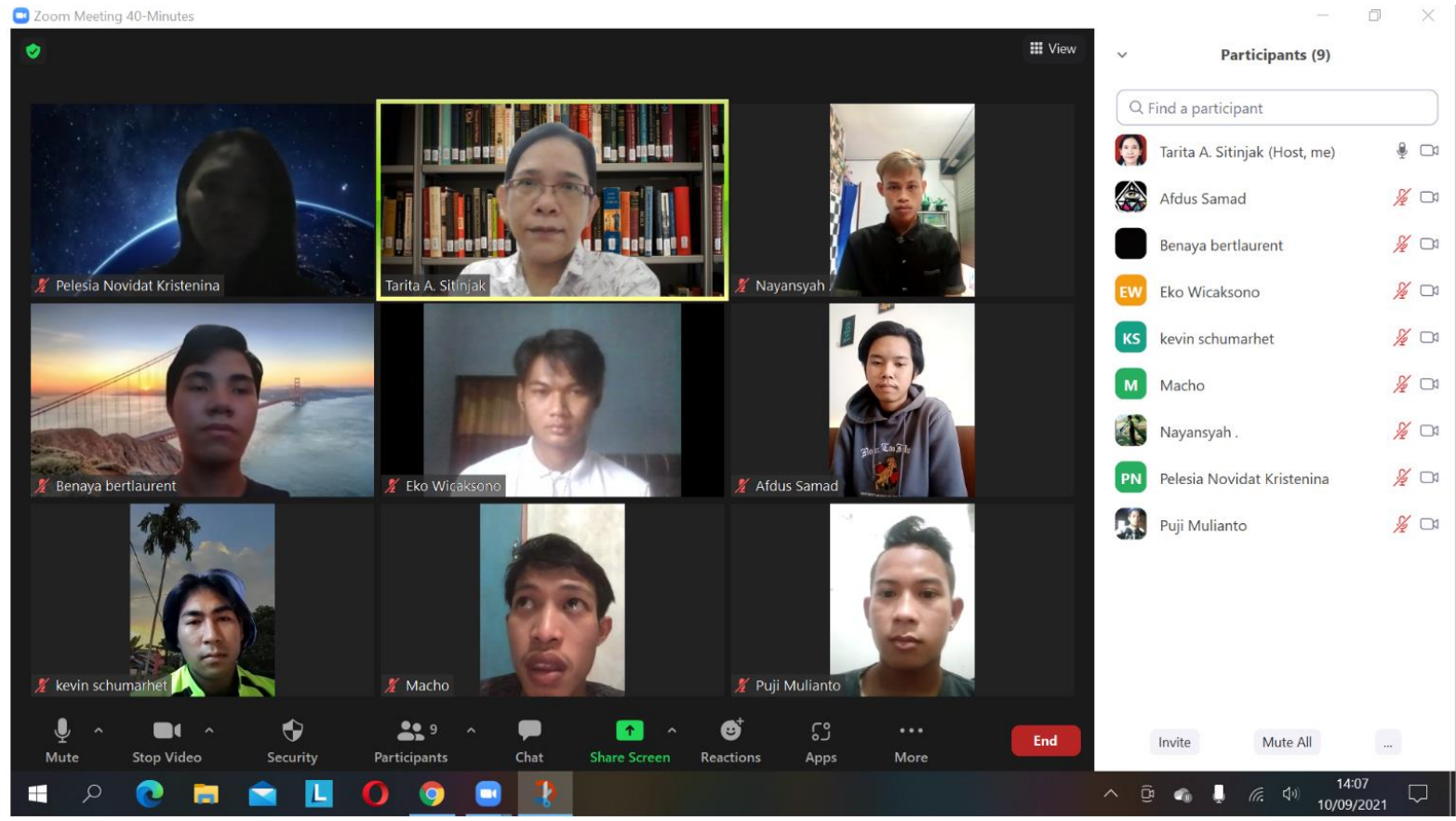

Gambar 3. PertemuanDengan Zoom Meeting (Kelompok 1 Dengan Metode Pembelajaran Self-Directed Learning)

\section{KESIMPULAN}

Sesuai dengan hasil penelitian dan analisis yang sudah diuraikan maka dapat ditarik kesimpulan sebagai berikut penerapan metode pembelajaran Self-Directed Learning memberikan pengaruh yang signifikan terhadap peningkatan hasil belajar mahasiswa yang mengambil matakuliah Teknik Lingkungan. Terdapat pengaruh yang signifikan dibuktikan dengan nilai sig (2tailed) untuk equal variances assumed adalah 0,000, dimana nilai equal variances assumed $=0,000<0,005$, hal ini menunjukkan bahwa maka ada perbedaan yang signifikan antara hasil belajar dengan metode konvensional dan metode Self-Directed Learning (SDL). Dengan menggunakan metode Self-Directed Learning nilai-nilai pada mata kuliah Teknik Lingkungan meningkat signifikan dari nilai rata-rata 49,4 menjadi 89,67 atau terjadi peningkatan nilai sebesar $80 \%$.

\section{SARAN}

Untuk menyelenggarakan Self-Directed Learning (SDL) terdapat beberapa hal yang perlu diperhatikan antara lain adalah:

1. Pengaturan alokasi waktu yang tepat dengan memberikan waktu yang cukup kepada mahasiswa untuk mempelajari secara mandiri materi perkuliahan dengan arahan dari dosen pengampu matakuliah.

2. Alokasi waktu bisa dimulai dengan formula awal 75:25 dalam artian bahwa $75 \%$ waktu digunakan untuk pembelajaran mandiri dan $25 \%$ waktu digunakan untuk pembelajaran kelas secara daring melalui zoom meeting.

3. Model pembelajaran Self-Directed Learning ini dilakukan berulang-ulang untuk pembiasaan kepada mahasiswa sehingga mahasiswa dapat lebih mandiri dan kreatif dalam belajar serta terbiasa untuk memecahkan masalah dengan cara berdiskusi.

\section{DAFTAR PUSTAKA}

Arikunto,Suharsimi.(2002). Prosedur Penelitian Suatu Pendekatan Praktik (Edisi Revisi Lima).Jakarta. PT Rineka Cipta.

Arikunto,(2010).Prosedur Penelitian Suatu Pendekatan Praktik (Edisi Revisi vi).Jakarta .PT Rineka Cipta.

Asmawi Zainul, Noehi Nasoetion, MA (2007). Penilain Hasil Belajar .P2T Universitas Terbuka.

Bersin, Josh. (2004). The Blended Beaming Book: Best Bractices, Proven Methodologies, and Lessons Learned. San Francisco: Pfeiffer.

Bonk, C.J., \& Graham, C.R. (2006). The Handbook of Blended Learning Environments: Global Perspectives, Local Designs. SanFransisco: JosseyBass/Pfeiffer.

Brunner, D.L. (2006). The Potential of the Self directed learning Course Vis-a-Vis Online and Traditional Courses," Teaching Theology and Religion, 9: 4, pp. 229235

Huda, Miftahul. (2013). Model-model Pengajaran dan Pembelajaran. Yogyakarta: Pustaka Pelajar.

Merriam, Sharan B. 2004. The Changing Landscape of Adult Learning Theory. Mahwah: Lawrence Erlbaum Associates.

Paramata N.R \&Sabudi N.H. (2020). Self-directed Learning Pada Mahasiswa Keperawatan Semester II Universitas Negri Gorontalo. JamburaNurshing Journal. Vol.2,No 1, Januari 2020 
Rachmawati, DewiOctova. (2010). Penerapan Model Self-directed Learning Untuk Meningkatkan Hasil Belajar dan Kemandirian Belajar Mahasiswa. Jurnal Pendidikan dan Pengajaran, Jilid 43, Nomor 3, Oktober 2010, hlm.177-184

Sugiyono (2009). Metode Penelitian Pendidikan, pendekatan kuantitatif, kualitatif, dan R\&D. Bandung: ALFABETA cv.

Sugiyono (2014). Metod Penelelitian kuantitatif, kualitatif, dan R\&D. Bandung: CV.ALFABETA
Trianto. (2013). Mendesain model pembelajaran inovatif-progresif : Konsep, Landasan, dan Implementasinya pada Kurikulum Tingkat Satuan Pendidikan (KTSP). Jakarta: KENCANA PRENADA MEDIA GROUP.

Zamnah L.N \& Ruswanan A.M. (2018). Penerapan Model Pembelajaran Self-directed Learning Untuk Meningkatkan Kemampuan Pemahaman Matematis Mahasiswa . Jurnal Pendidikan Matematika Indonesia. Volum 3 Nomor 2 Bulan September 2018 Page 52 - 56 